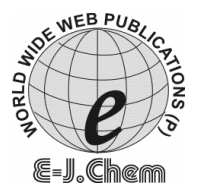

http://www.e-journals.net
CODEN ECJHAO

E-Journal of Chemistry

Vol. 3, No.1, pp 1-4, January 2006

\title{
Ultrasound Promoted Synthesis of 3-Carboxycoumarins in Aqueous Media
}

\author{
JIAN-LONG DU*, LI-JUN LI and DA-HAI ZHANG \\ College of Chemistry \& Environmental Science, \\ Hebei University, Baoding 071002, P.R. China
}

Received 20 August 2005; Revised 19 October 2005; Accepted 23 January 2006

\begin{abstract}
An efficient and green procedure has been developed for synthesis of 3 -carboxycoumarins, the reaction can be carried out in water under ultrasound irradiation, avoiding addition of catalyst
\end{abstract}

Key words: Green synthesis; 3-Carboxycoumarins; Ultrasound.

\section{Introduction}

Coumarins are well known natural products for their diverse biological activity. ${ }^{1}$ Coumarin derivatives display a broad range of applications to the pharmaceutical, perfume and cosmetic industries. ${ }^{2}$ They are also exploited as intermediates and building blocks in organic synthesis. ${ }^{3-4} 3$-carboxycoumarins are an important initial compounds for the synthesis of coumarins, they are traditionally prepared by Knoenenagel condensation of 2-hydroxybenzaldehydes with active methylene compounds. ${ }^{5-9}$ But the reported methods always suffer from drawbacks such as long reaction time, high temperature, or necessary catalyst.

Ultrasound irradiation has been increasingly used in organic synthesis in last three decades. Comparing with traditional methods, this method is more conveniently and easily controlled. A large number of organic reactions have been carried out in higher yield, shorter reaction time and milder condition under ultrasound irradiation. ${ }^{10-12}$ In all reactions, organic solvents are always being used. Recently organic reactions in water without use of harmful organic solvents have drawn much more attention, because water is a cheap, safe and environmentally benign solvent. ${ }^{13-15}$ In the course of our investigation to develop new green synthetic method, we would like to report ultrasound assisted synthesis of 3-carboxycoumarins in water (Scheme 1). 


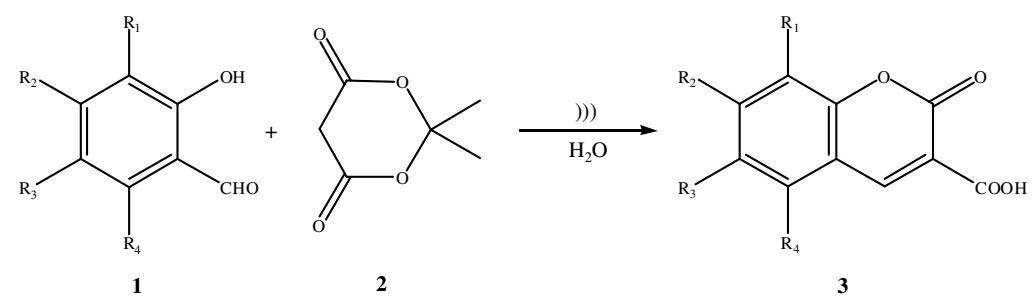

Scheme 1. Synthesis of 3-carboxycoumarins

\section{Experimental}

All starting salicylaldehydes were commercially available. Meldrum's acid (2, 2-dimethyl-1, 3-dioxan-4, 6-dione) was prepared according to literature procedure.$^{20}$ Melting points were uncorrected. IR spectra were recorded on a Bio-Rad FTS-40 spectrometer (KBr). ${ }^{1} \mathrm{H}$ NMR spectra were measured on VXR-300 S (300 MHz) spectrometer using TMS as internal standard and DMSO- $d_{6}$ as solvent. Mass spectra were determined on a VG-7070 E spectrometer (EI, $70 \mathrm{eV}$ ). Sonication was performed in a Shanghai Branson-CQX ultrasonic cleaner with a frequency of $25 \mathrm{kHz}$ and a nominal power $500 \mathrm{~W}$. The reaction flask was located in the maximum energy area in the cleaner, and the addition or removal of water controlled the temperature of the water bath.

\section{General procedure}

A suitable salicylaldehyde (1, 1mmol), Meldrum's acid (2, 2-dimethyl-1, 3-dioxan-4, 6dione) $(2,1 \mathrm{mmol})$, and water $(5 \mathrm{ml})$ were added in a Pyrex flask. The mixture was irradiated in the water bath of an ultrasonic cleaner for an hour. After cooling to room temperature the solid product was filtered on Buchner, washed by water and dried under vacuum. The purification from traces of starting salicylaldehydes, if necessary, was performed by recrystallization from methanol or ethyl acetate. The authenticity of the products was established by comparing their melting points with the literature and by the spectra data of IR, MS and ${ }^{1} \mathrm{H}$ NMR. Selected data of some compounds are shown below:

3a: IR (KBr): $3215(\mathrm{OH}), 1740(\mathrm{C}=\mathrm{O}), 1680(\mathrm{C}=\mathrm{O}), 1613 \mathrm{~cm}^{-1}(\mathrm{C}=\mathrm{C}) .{ }^{1} \mathrm{H}$ NMR (DMSO- $\left.d_{6}\right)$ : $\delta=7.37$ (t, $1 \mathrm{H}, \mathrm{H}-6), 7.42$ (d, $1 \mathrm{H}, \mathrm{H}-8), 7.71$ (ddd, $1 \mathrm{H}, \mathrm{H}-7$ ), 7.89 (dd, $1 \mathrm{H}, \mathrm{H}-5), 8.76$ (s, $1 \mathrm{H}, \mathrm{H}-4)$. MS: $\mathrm{m} / \mathrm{z}(\%) 190\left(\mathrm{M}^{+}, 31\right)$.

3b: IR (KBr): $3223(\mathrm{OH}), 1740(\mathrm{C}=\mathrm{O}), 1690(\mathrm{C}=\mathrm{O}), 1623 \mathrm{~cm}^{-1}(\mathrm{C}=\mathrm{C}) .{ }^{1} \mathrm{H}$ NMR (DMSO$\left.d_{6}\right): \delta=4.05,\left(\mathrm{~s}, 3 \mathrm{H}, \mathrm{OCH}_{3}\right), 7.07-7.18(\mathrm{~m}, 2 \mathrm{H}, \mathrm{H}-6,8), 7.92(\mathrm{~d}, 1 \mathrm{H}, \mathrm{H}-5), 8.91$ (s, $1 \mathrm{H}, \mathrm{H}-$ 4). MS: m/z (\%) $220\left(\mathrm{M}^{+}, 48\right)$.

3d: IR (KBr): $3195(\mathrm{OH}), 1742(\mathrm{C}=\mathrm{O}), 1678(\mathrm{C}=\mathrm{O}), 1621 \mathrm{~cm}^{-1}(\mathrm{C}=\mathrm{C}) .{ }^{1} \mathrm{H}$ NMR (DMSO$\left.d_{6}\right): \delta=7.46,(\mathrm{~d}, 1 \mathrm{H}, \mathrm{H}-8), 7.76(\mathrm{dd}, 1 \mathrm{H}, \mathrm{H}-7), 8.03$ (d, $\left.1 \mathrm{H}, \mathrm{H}-5\right), 8.68$ (s, $\left.1 \mathrm{H}, \mathrm{H}-4\right)$. MS: $\mathrm{m} / \mathrm{z}(\%) 189\left(\mathrm{M}^{+}-\mathrm{Cl}, 100\right)$.

3f: IR (KBr): $3182(\mathrm{OH}, \mathrm{COOH}), 1722(\mathrm{C}=\mathrm{O}), 1689(\mathrm{C}=\mathrm{O}), 1617 \mathrm{~cm}^{-1}(\mathrm{C}=\mathrm{C}) .{ }^{1} \mathrm{H}$ NMR $\left(\right.$ DMSO- $d_{6}$ ): $\delta=6.74,(\mathrm{~d}, 1 \mathrm{H}, \mathrm{H}-8), 6.85$ (dd, $\left.1 \mathrm{H}, \mathrm{H}-6\right), 7.76$ (d, $\left.1 \mathrm{H}, \mathrm{H}-5\right), 8.66$ (s, $1 \mathrm{H}, \mathrm{H}-$ 4), 11.17 (br s, $1 \mathrm{H}, \mathrm{OH})$. MS: m/z (\%) $206\left(\mathrm{M}^{+}, 38\right)$. 


\section{Results and Discussion}

Table 1. Solvent effect on the yields of 3a.

\begin{tabular}{llll}
\hline Entry & Solvent & Time $(\min )$ & Yield (\%) \\
\hline $\mathbf{1}$ & $\mathrm{H}_{2} \mathrm{O}$ & 60 & 90 \\
$\mathbf{2}$ & EtOH & 60 & 65 \\
$\mathbf{3}$ & 1, 4-Dioxane & 60 & 62 \\
$\mathbf{4}$ & DMF & 60 & 54 \\
$\mathbf{5}$ & $\mathrm{ClCH}_{2} \mathrm{CH}_{2} \mathrm{Cl}$ & 60 & 30 \\
\hline
\end{tabular}

Table 2. Synthesis of 3-carboxycoumarins in water under ultrasound.

\begin{tabular}{|c|c|c|c|c|c|c|c|}
\hline \multirow[t]{2}{*}{ Entry } & \multirow[t]{2}{*}{$\mathrm{R}_{1}$} & \multirow[t]{2}{*}{$\mathrm{R}_{2}$} & \multirow[t]{2}{*}{$\mathrm{R}_{3}$} & \multirow[t]{2}{*}{$\mathrm{R}_{4}$} & \multirow{2}{*}{$\begin{array}{l}\text { Yield } \\
(\%)\end{array}$} & \multicolumn{2}{|c|}{$\mathrm{Mp}$} \\
\hline & & & & & & Found & Lit \\
\hline $\mathbf{a}$ & $\mathrm{H}$ & $\mathrm{H}$ & $\mathrm{H}$ & $\mathrm{H}$ & 90 & $191-192$ & $191-192^{16}$ \\
\hline b & $\mathrm{H}$ & $\mathrm{CH}_{3} \mathrm{O}$ & $\mathrm{H}$ & $\mathrm{H}$ & 86 & 193-194 & $192-193^{17}$ \\
\hline c & $\mathrm{CH}_{3} \mathrm{O}$ & $\mathrm{H}$ & $\mathrm{H}$ & $\mathrm{H}$ & 91 & $216-217$ & $218-219^{18}$ \\
\hline d & $\mathrm{H}$ & $\mathrm{H}$ & $\mathrm{Cl}$ & $\mathrm{H}$ & 81 & $120-121$ & $120-121^{16}$ \\
\hline $\mathbf{e}$ & $\mathrm{H}$ & $\mathrm{H}$ & $\mathrm{CH}_{3}$ & $\mathrm{H}$ & 93 & $167-168$ & $166-167^{18}$ \\
\hline $\mathbf{f}$ & $\mathrm{H}$ & $\mathrm{OH}$ & $\mathrm{H}$ & $\mathrm{H}$ & 83 & $258-259$ & $261-263^{16}$ \\
\hline g & $\mathrm{H}$ & $\mathrm{H}$ & $\mathrm{CH}_{3} \mathrm{O}$ & $\mathrm{H}$ & 95 & $208-209$ & $206-207^{18}$ \\
\hline h & $\mathrm{H}$ & $\mathrm{H}$ & $\mathrm{CH}-\mathrm{Cl}$ & & 87 & $236-237$ & $236-237^{16}$ \\
\hline
\end{tabular}

The results are summarized in Table 1 and 2. It can easily be seen that the condensation of a series of salicylaldehydes with Meldrum's acid leading to corresponding 3-carboxycoumarins in good yields $(81 \%-95 \%)$ in water under ultrasound irradiation, without adding any catalyst. In this reaction, excess of Meldrum's acid should be avoided because it may react with 3-carboxycoumarins leading to a decrease of yield and purity. ${ }^{19}$

To investigate the reaction we first examined the solvent effect on the reaction. The data (Table 1) show that the reaction is favored in water, although it involves the elimination of a molecule of water. Similar solvent effect has been previously found. ${ }^{9}$ Although the reaction can be carried out in ethanol or 1,4-Dioxane solvent giving a good result (yield in $65 \%, 62 \%$ ), we suggest that water is the best solvent because it agreements the Meldrum's acid dissociation, due to its high $\varepsilon$ value, that generates the nucleophilic species able to attack the aldehydic carbon, at the same time it also offers some advantages, such as its low cost, no inflammability. This mild reaction could be used to different substituted salicylaldehydes $\mathbf{1}$ furnishing the corresponding product $\mathbf{3}$ in good yields. It is noteworthy that all of the products $\mathbf{3}$ were easily isolated by simple Buchner filtration (Table 2).

We propose the possible following mechanism (Scheme 2) to account for the reaction. At first, Meldrum's acid $\mathbf{2}$ dissolve in water giving the nucleophilic species, it attack the aldehydes 1 to afford arylidene derivatives 4 . The step $(\mathbf{1}+\mathbf{2} \rightarrow \mathbf{4})$ can be regarded as a fast knoevenagel condensation, the reaction can be carried out in water without any catalyst under ultrasound irradiation according to our previous research. ${ }^{15}$ Then the intermediate 4 is cyclized by the nucleophilic attack of $\mathrm{OH}$ group on the carbonyl $(\mathrm{C}=\mathrm{O})$ moiety and give the intermediate 5, finally the expected products $\mathbf{3}$ are afforded through the proton $\left(\mathrm{H}^{+}\right)$transfer. 


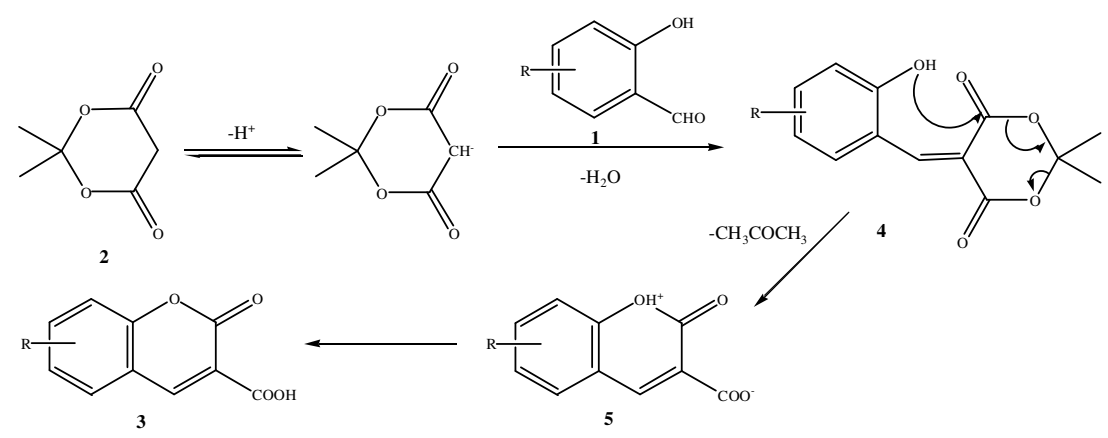

Scheme 2. The possible mechanism of the reaction

\section{Conclusion}

In summary, we have found a practical and green synthesis procedure for preparing 3carboxycoumarins by condensation of substituted salicylaldehydes and Meldrum's acid in water under ultrasound.

\section{Acknowledgements}

We acknowledge the Foundation of Hebei University (Q200404).

\section{References}

1 Murray R D, Mendez J, Brown S A The Natural Coumarins: Occurrence, Chemistry and Biochemistry; John Wiley \& Sons: New York, 1982.

2 Meuly W C Kirk-Othmer Encyclopedia of Chemical Technology; 3rd ed.; John Wiley \& Sons: New York, 1979; vol. 7, 196.

3 Bissel E R, Mitchell A R, Smith R E J. Org. Chem. 1980, 45, 2283.

4 Versleijen J P G, Van Leusen A M, Feringa B L Tetrahedron Lett. 1999, 40, 5803.

5 Maggi R, Bigi F, Carloni S, Mazzacani A, Sartori G Green Chem. 2001, 3, 173.

6 Shirokova E A, Segal G M, Torgov I V Bioorganicheskaya Khimiya 1988; vol.14, 236.

7 Bandgar B P, Uppalla L S, Kurule D S Green Chem. 1999, 1, 243.

8 Bandgar B P, Uppalla L S, Sadavarte V S J. Chem. Res. (Synopses) 2002, 40.

9 Waston B T, Christiansen G E Tetrahedron Lett. 1998, 39, 6087.

10 Li J T, Han J H, Yang J H and Li T S Ultrason. Sonochem. 2002, 9, 237.

11 Li J T, Chen G F, Yang W Z, Li T S Ultrason. Sonochem. 2003, 10, 123.

12 Li J T, Chen G F, Xu W Z, Li T S Ultrason. Sonochem. 2003, 10,115.

13 Bigi F, Chesini L, Maggi R, Sartori G J. Org. Chem. 1994, 64, 1033.

14 Bigi F, Conforti M L, Maggi R, Piccinno A, Sartori G Green Chem. 2000, 2, 101.

15 Du J-L, Li L-J and Li Y F Chem: An Indian J. (in press).

16 Song A, Wang X, Lam K S Tetrahedron lett. 2003, 44, 1755.

17 Fringuelli F, Piermatti O, Pizzo F Synthesis 2003, 15, 2331.

18 Bigi F, Chesini L, Maggi R, Satori G J. Org. Chem. 1999, 64, 1033.

19 Hedge J A, Kruse C W, Snyder H R J. Org. Chem. 1961, 26, 3166.

20 Davidson D, Bernhardt S A J. Am. Chem. Soc., 1948, 70, 3426. 


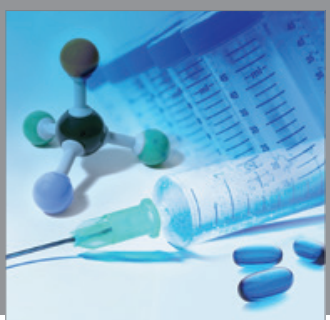

International Journal of

Medicinal Chemistry

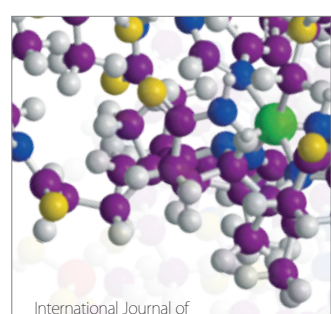

Carbohydrate Chemistry

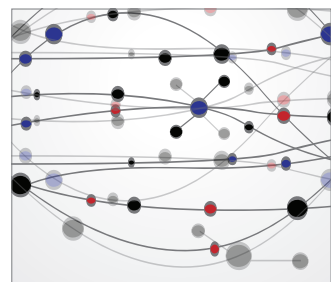

The Scientific World Journal
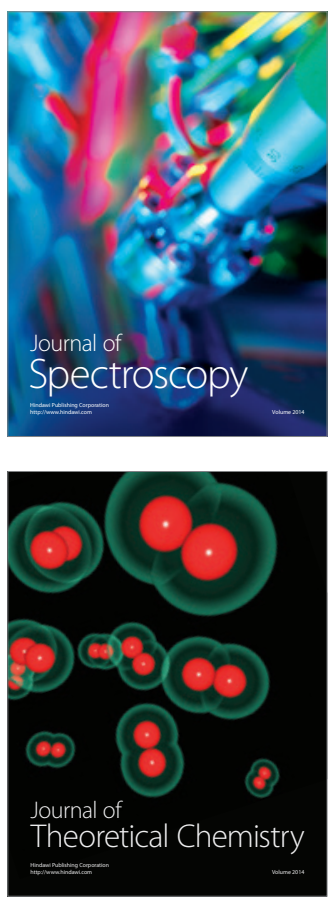
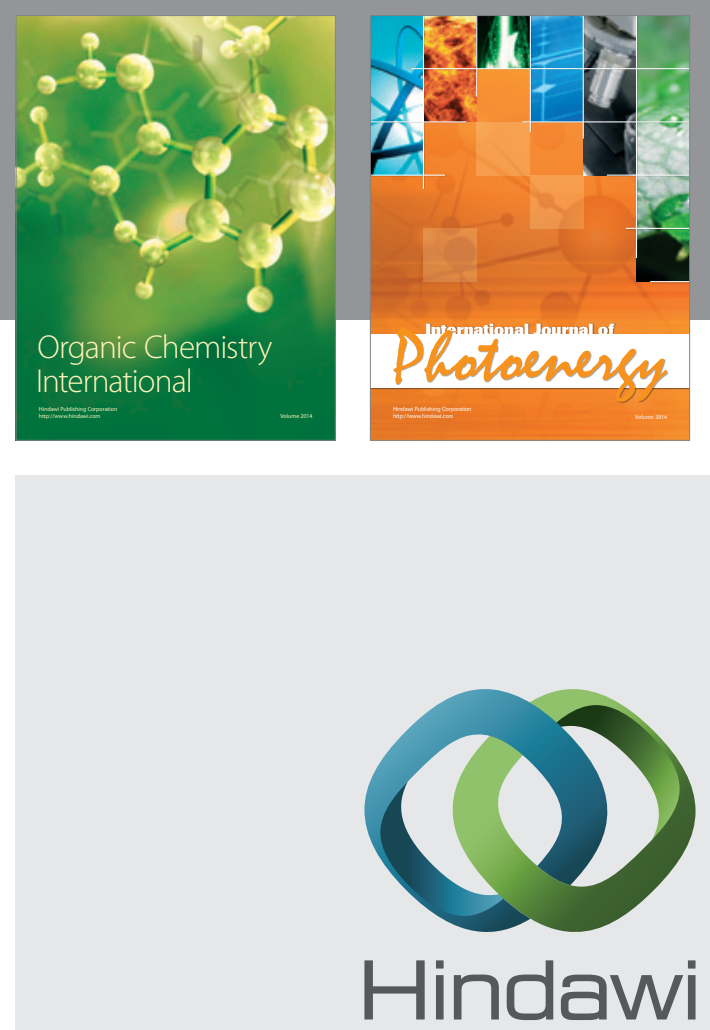

Submit your manuscripts at

http://www.hindawi.com
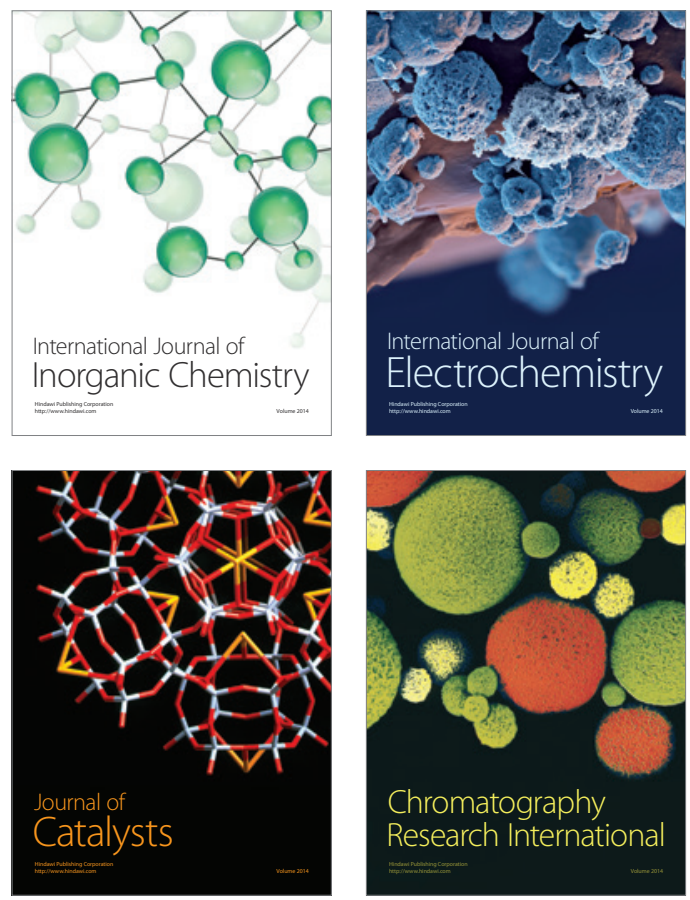
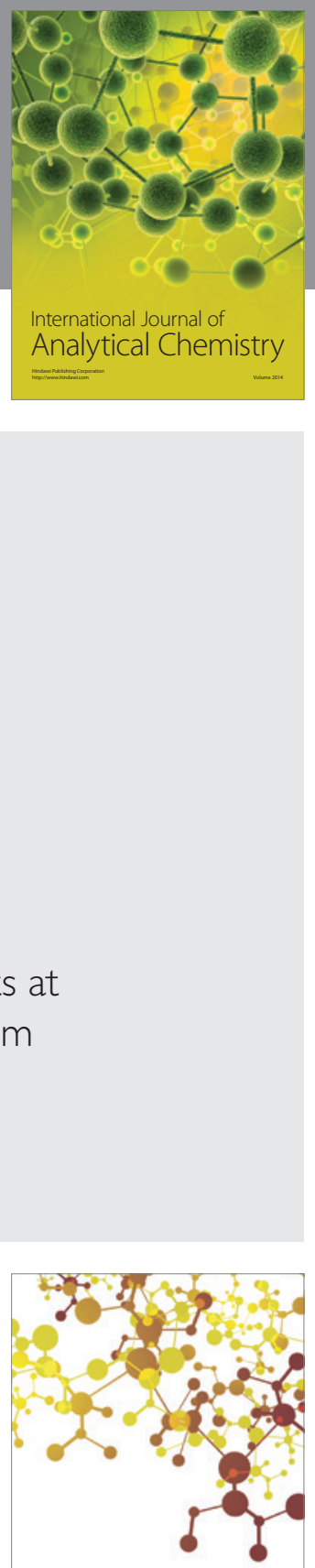

Journal of

Applied Chemistry
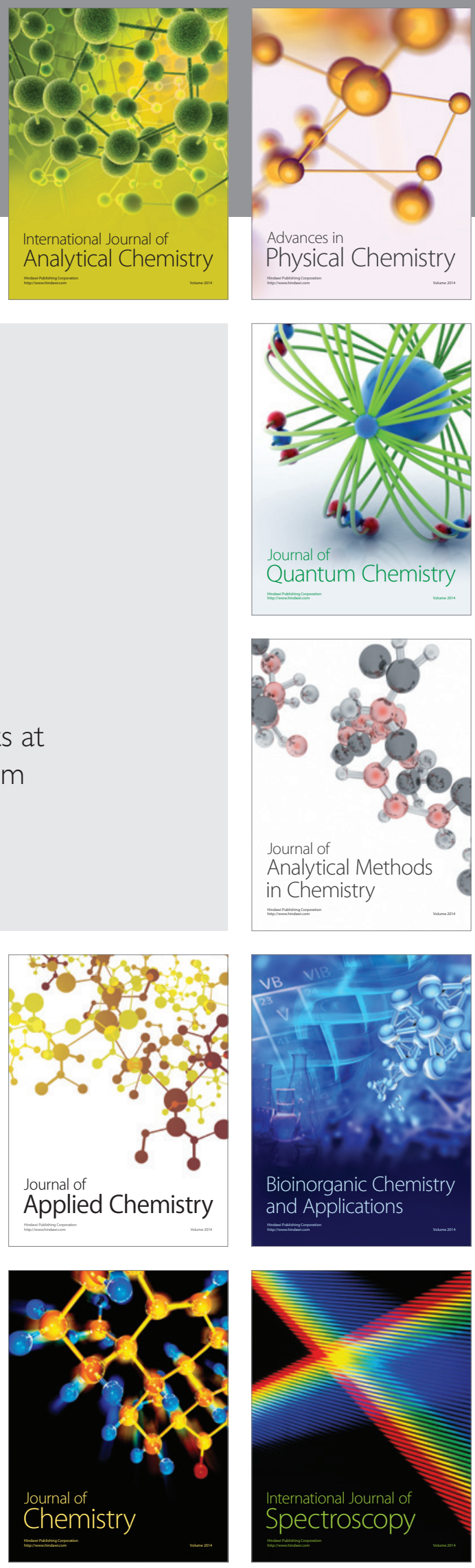